\title{
Peran Perguruan Tinggi dalam Pemberdayaan Masyarakat Melalui Bank Mikro Wakaf
}

\author{
Rimanto $^{* 1}$, Kholid Hidayatullah ${ }^{2}$, Muhamad Rudi Wijaya ${ }^{3}$ \\ 1,2Universitas Pringsewu, Lampung, Indonesia; 3 STIS Darul Ulum Lampung \\ Timur, Lampung, Indonesia \\ Email: ${ }^{* 1}$ rimanto@umri.ac.id, ${ }^{2}$ kholidhidayat.kh@gmail.com, \\ ${ }^{3}$ rudiwijaya68@gmail.com
}

\begin{abstract}
Waqf plays a very significant economic and social position in Islamic history. Waqf acts as a source of financing for worship, education, social and public services. Many developments in the Islamic economic sector or Islamic banking are related to waqf, not least in 2017 the Government together with the OJK initiated the existence of a Micro Waqf Bank as an effort to answer the problem of poverty, in collaboration with Islamic boarding schools in Indonesia. using primary and secondary data using descriptive qualitative analysis. The results of this research prove that the term Micro Waqf Bank was chosen because the government wants the core of the funds distributed to the community to be maintained in principle without reducing the benefits, not only that it is called Micro Waqf Bank because the BWM operation is located in a boarding school area. Throughout the development of this BWM, using the term micro waqf bank in naming the institution, but from the legal basis and the form of the legal entity it is very far from the name. The legal entity of BWM is a cooperative, on the other hand, the business license of BWM is a sharia microfinance agency, so its supervision is under the Financial Services Authority. The involvement of Universities in the context of community service for community empowerment is very strategic in order to carry out complete human development, and in the context of community empowerment and Micro Waqf Bank instruments have the potential for community economic development, especially in the pesantren environment, to create an empowered, independent and independent society.
\end{abstract}

Keywords: Community Empowerment, Bank, Micro Wakaf

\section{Abstrak}

Wakaf memainkan kedudukan ekonomi serta sosial yang sangat berarti dalam histori Islam. Wakaf berperan sebagai sumber pembiayaan untuk sarana ibadah, pendidikan, pelayanan sosial 
serta publik. Banyak pengembangan sektor ekonomi Islam ataupun perbankan syariah yang berhubungan dengan wakaf, tidak terkecuali di tahun 2017 Pemerintah bersama OJK menginisiasi adanya Bank Wakaf Mikro sebagai usaha menjawab permasalahan kemiskinan, yang berkolaborasi dengan badan berplatform pesantren di Indonesia, Penelitian ini memakai tata cara penelitiaan library riseart dengan memakai data primer dan sekunder dengan memakai analisa deskriptif kualitatif. Hasil riset ini membuktikan bahwa Istilah Bank wakaf mikro dipilih karena pihak pemerintah menginginkan agar inti dari dana yang disebar ke masyarakat senantiasa terpelihara pokoknya tanpa kurangi manfaatnya, tidak hanya itu dinamai Bank Wakaf Mikro disebabkan operasi BWM ini terletak di kawasan pesantren. Sepanjang perkembangannya BWM ini, memakai sebutan bank wakaf mikro dalam penamaan lembaganya akan tetapi dari dasar hukum serta bentuk dari badan hukumnya justru amat jauh dari penamaannya. Badan hukum dari BWM ini merupakan Koperasi, sebaliknya izin upaya BWM merupakan badan finansial mikro syariah maka pengawasannya terletak di bawah Otoritas Jasa Keuangan. Keterlibatan pihak Perguruan Tinggi dalam rangka pengabdian masyarakat guna pemberdayaan masyarakat sangatlah strategis guna melakukan pembangunan manusia seutuhnya, dan dalam rangka pemberdayaan masyarakat dan instrumen Bank Wakaf Mikro sangat potensial untuk pengembangan ekonomi masyarakat khususnya di lingkungan pesantren, untuk menciptakan masyarakat yang berdaya, mandiri dan merdeka

Kata Kunci: Pemberdayaan Masyarakat, Bank, Mikro Wakaf

\section{PENDAHULUAN}

Wakaf sebagai lembaga filantrofi Islam sejak awal disyariatkan menampilkan peran yang sangat elegan, di samping sebagai media pemenuhan ketaatan kepada Allah SWT dan sebagai bagian bentuk penghambaan, pada saat yang bersamaan menjadi sarana sosial, baik ekonomi maupun sosial kemanusiaan. Peran wakaf secara luas telah menhadirkan peradaban manusia yang cukup berhasil dan menjadikan wakaf sebagai instrumen penting dalam mewarnai dan memajukan peradaban itu sendiri.

Perjalanan pemaknaan wakaf telah mengalami evolusi interpretasi dan implikasi. Hal ini terlihat dalam perkembangan wakaf yang tidak saja diartikan 
sebagai ibadah yang berkaitan dengan relasi manusia dengan Tuhan semata, akan tetapi wakaf dijadikan solusi problematika sosial. Wakaf diformulasikan sebagai instrumen keekonomian yang strategis dan perfektif solutif. Pengembangan wakaf sebagai perfektif solutif, terus mengalami perkembangan mengikuti perkembangan sosial, wakaf dipahami dengan pendekatan multidisipliner (pendekatan ekonomi) menghasilkan pelembagaan wakaf dengan lembaga pembiayaan produktif yang menggunakan azas dan manajemen modern yang berintegrasi dengan nilai-nilai Islam (syaria'ah).

Wakaf tunai sebagai hasil ijtihad telah membuktikan mampu membantu dan dan meringankan problem ekonomi di berbagai negara Islam, akan tetapi kemampuan dan keberhasilan tersebut tidak serta merta diterima dengan baik oleh kebanyakan masyarakat muslim Indonesia, hal ini ditengarai oleh rendahnya pemahaman literasi wakaf yang terus mengalami grudual. Wakaf hanya dipahami sebatas wakaf untuk kepentingan ibadah, (wakaf konsumtif) padahal wakaf jika dipahami dengan baik, bisa menjadi instrumen ekonomi yang handal, dan bisa dijadikan salah salah satu pilar pembangunan ekonomi sosial keumatan.

\section{METODE PENELITIAN}

Adapun jenis penelitian yang digunakan adalah jenis penelitian library research. Adapun yang dimaksud dengan library research adalah teknik pengumpulan data dengan mengadakan studi penelaahan terhadap buku-buku, literatur-literatur, catatan-catatan dan laporan-laporan yang ada hubungannya dengan masalah yang dipecahkan (M. Nazir, 2006:27). Dengan demikian, dengan menggunakan metode library research seorang peneliti melakukan penelitan dengan menjadikan literatur-literatur yang ada hubungannya dengan objek penelitian sebagai objek kajian, pengamatan, penelaahan /analisa dan kemudian menyimpulkan. Data data yang diketemukan berupa hasil obsevasi, pengamatan, interview dan dokumentasi dijadikan sumber data penelitian disamping data data pustaka.

Dengan demikian jenis penelitian yang digunakankan peneliti adalah menggabungkan kedua jenis penelitian di atas sebagai cara peneliti memperoleh sumber-sumber data, baik data primer maupun data skunder, yang 
kemudian dianalisa dengan metode diskripsi analisis. Yaitu untuk membuat deskripsi/gambaran atau lukisan secara sistematis, factual dan akurat mengenai fakta - fakta, sifat - sifat serta hubungan antara fenomena yang diselidiki (Muhammad Musa, 1988:8). Dari diskripsi tersebut kemudian ditarik sebuah kesimpulan.

\section{HASIL DAN PEMBAHASAN}

Peran Perguruan Tinggi dalam Memberdayakan Masyarakat melalui Bank Mikro Wakaf

1. Hakikat Perguruan Tinggi

Perguruan Tinggi secara harfiah dapat ditafsirkan, kata "Perguruan" sama dengan tempat belajar, tempat berbagi pengetahuan, tempat berkreasi dan berekspresi atau tempat mengaktualisasikan kreativitas diri dalam berbagai bentuk. Sementara kata "Tinggi" menunjukan tingkatan atau jenjang, bahwa mereka (mahasiswa) merupakan orang yang sudah mempunyai potensi awal. Artinya mereka yang belajar di PT merupakan orang setengah jadi dalam hal kapasitas intelektual, emosional, termasuk spiritual. Jadi secara sederhana terminologi PT adalah tempat belajarnya para calon intelektual dan cendikiawan. Sebagai pusat peradaban, PT harus mampu mengembangkan teori-teori yang sudah ada, menguji keabsahan teori-teori yang ada, menciptakan teori-teori baru sehingga menghasilkan ilmu-ilmu yang aktual dan kontekstual untuk kemajuan masyarakat secara umum. Di samping itu, bukan hanya sekedar teori yang mereka kembangkan di sana, aktualisasi dari teori atau gagasan-gagasan lain pun harus berpusat di PT. Sebagai Sebagai pusat syiar (dakwah), PT harus mampu berperan merubah paradigma pikir masyarakat ke arah yang lebih terbuka (inklusif). PT harus bisa menerangi masyarakat dari belenggubelenggu kebodo keterbelakangan dan ketidakberdayaan. Di samping itu, PT harus mampu mengajak dan membawa masyarakat ke arah kehidupan yang lebih maju/maslahat, baik dalam kontek duniawi maupun ukhrowi.

2. Tugas Dan Fungsi Perguruan Tinggi

Keberadaan Perguruan Tinggi (PT) di tengah-tengah masyarakat sebenarnya menjadi kebanggaan tersendiri. Setidaknya, PT akan berdampak positif bagi kemajuan sosial. Dampak positif tersebut dapat berupa 
kemajuan cara berpikir dan pola gerak (perilaku) masyarakat. Kemajuan berpikir ditandai dengan tingkat pengetahuan masyarakat yang lebih luas dan komprehensif dalam menghadapi realitas kehidupan yang semakin kompleks. Masyarakat tidak lagi sempit dalam memahami dan menyikapi perubahan yang terjadi. Kelanjutan berpikir sementara pola perilaku berkembang. Ketika pola pikir masyarakat terbuka, maka menghasilkan sikap yang lebih dinamis, bijaksana, dan lebih bebas mewujudkan perilaku dengan mengedepankan prinsip-prinsip yang diyakini kebenarannya. Yang pasti, PT sangat penting untuk membawa angin segar bagi kemajuan masyarakat. PT lahir dari tiga tugas utama di masyarakat: pendidikan, penelitian dan pengabdian(Sayan Suryana, 2018:368-379).

Pertama, tugas melaksanakan pendidikan. Dengan tugas ini, PT harus mendidik masyarakatnya untuk menjadi lebih cerdas dan bijaksana. Oleh karena itu, ketika manusia menjadi arif, cerdas, dan bijaksana, maka akan menghasilkan kualitas manusia yang unggul. Masyarakat menjadi lebih kreatif dan mandiri dalam memecahkan masalah kehidupan, termasuk ekonomi, sosial budaya dan politik. Dengan kemandirian masyarakat, setidaknya akan mengurangi pengaruh eksternal yang tidak terlalu membantu masyarakat. Tapi sebaliknya, itu menjengkelkan.

Kedua, tugas penelitian. Dengan misi ini, peran PT bukan hanya mentransfer ilmu pengetahuan kepada masyarakat dengan mengakibatkan ekses dari kondisi masyarakat tidak tahu menjadi tahu. PT harus mampu meneliti fenomena- fenomena sosial dan alam untuk menghasilkan satu penemuan-penemuan baru. Dengan demikian, keilmuan yang ada bukan hanya ilmu yang statis melainkan ilmu yang dinamis, aktual dan ilmu yang mampu menjawab atau memecahkan berbagai persoalan yang ada. Sehingga nantinya ada harmonisasi antara teori yang dipelajari di PT dengan realitas kehidupan masyarakat.

Ketiga, tugas pengabdian. Dengan misi ini, PT diharuskan menjadi bagian dari masyarakat. Tentunya, PT harus dekat dengan masyarakat dan paham terhadap realitas psikologis, sosiologis-antropologis, politis dan ekonomi masyarakat. PT harus membaurkan diri dengan masyarakat dalam membimbing secara langsung terkait dengan persoalan-persoalan yang 
dihadapi. PT harus bisa merubah masyarakat dari tidak berdaya menjadi masyarakat berdaya, mandiri dan syukur-syukur madani.

Singkatnya, PT harus menjadi agen perubahan (agen of social change) di masyarakat dalam semua aspek kehidupan. Tentunya, perubahan dimaksud bukan perubahan ke arah regress (kemunduran), melainkan ke arah progress (kemajuan). Perubahan ke arah progress memerlukan proses dan waktu. PT harus mampu menembus pola kehidupan masyarakat ke arah masyarakat sadar, bukan masyarakat tahu. Masyarakat sadar ialah masyarakat yang sudah bisa memahami hakikat dirinya dan di luar dirinya dalam menghadapi kehidupan. Sehingga watak yang muncul ialah watak yang siap memberikan yang terbaik untuk kemaslahatan bersama. Sementara, masyarakat tahu, belum sampe ke arah sana, melainkan hanya bisa memahami dirinya. Maka, jangan heran bila watak- watak egoisme lebih dominan.

3. Pemberdayaan Masyarakat

Pemberdayaan berawal dari kata" daya", yang berarti daya ataupun“ kemampuan", yang dalam bahasa Inggris lebih diketahui dengan" Power". Selanjutnya disebut pemberdayaan ataupun empowerment, sebab mempunyai arti perencanaan, cara serta usaha penguatan ataupun memampukan yang lemah (Rahman Mulyawan,2016).

Pemberdayaan ialah ide yang timbul dari sebab proses berkembangnya kemajuan alam pikir serta kultur sosial barat, terutamanya Eropa. Rancangan ini timbul semenjak dasawarsa 70- an serta setelah itu lalu bertumbuh hingga sekarang ini. Ide ini muncul berrsamaan dengan maraknya mazhab-,mazhab yang sangat terkenal semacam aliran eksistensialisme, aliran phenomenologi, dan personalisme. Lalu semakin berkembang dan dianggap sebagai perpanjangan pemikiran dari aliran neo marxisme, dan aliran sosiologi seperti freudianisme, strukturalisme, dan Frankfurt School. Berbarengan itu pula timbul konsep- konsep elit, kewenangan, anti- establishment, aksi populis, anti- struktur, legalitas, pandangan hidup pembebasan serta civil society. Konsep pemberdayaan dianggap juga sebagai bagian dari gerakan post- modernisme sebuah gerakan yang muncul di paruh era ke- 20, yang penekanannya pada 
perilaku serta pandangan yang gerakannya merupakan pandangan antisistem, anti- struktur serta anti- determinisme yang ada pada lingkaran kekuasaan. Sedangkan pemberdayaan masyarakat secara terminologi mulai dipopulerlan di Indonesia semenjak tahun 1980- an. Pada mulanya lebih diketahui dengan program- program pemberdayaan yang dilaksanakan oleh Lembaga Swadaya Masyarakat( LSM) ataupun lembaga non penguasa (NGO), tetapi saat ini sudah jadi satu skema pemberdayaan masyarakat untuk mengurangi tingkat kemiskinan yang diadopsi oleh lembagalembaga pemerintah. (Rahman Mulyawan,2016)

Menurut Prijono, S. Onny serta Pranarka, A. Meter. W( 1996) pemberdayaan ialah cara penguatan individu- individu ataupun warga supaya mereka berkemampuan. Mendorong ataupun memotivasi mereka supaya memiliki keahlian ataupun keberdayaan dalam memastikan pilihan hidupnya. Pemberdayaan bisa dikatakan sebagai metode dan tujuan. Sebagai cara pemberdayaan ialah serangkaian aktivitas buat menguatkan daya kalangan lemah dalam masyarakat. Sedangkan sebagai tujuan, pemberdayaan untuk menciptakan transformasi sosial ialah membuat masyarakat ataupun kelompok dan pribadi menjadi berdaya sehingga mampu dalan pemenuhan hidupnya seperti pemenuhan hak fisik, ekonomi serta sosial (Zubaidi,2013).

Pengembangan masyarakat dilandasi sebuah harapan kalau masyarakat mampu membawa tanggung jawab dan terlibat dan merumuskan kebutuhan, menggapai kesejahteraan, peninggakatan kwalitas sumber daya serta mampu menciptakan tujuan masa depan sendiri. Tujuan pengembangan masyarakat diarahkan untuk mengembangkan supportive communities, yaitu masyarakat yang orientasinya dilandaskan pada arah pengembangan dan peningkatan sumber daya secara proposional dan terlibat dalam proses interaksi sosial. pengembangan masyarakat pada dasarnya sebuah aktualisasi para penggerak sosial dalam mencari solusi dalam setiap permasalahan dan mengurangi bahkan menghilangkan dari kesenjangan antar golongan dalam sebuah komunitas dalam masyarakat, termasuk menanggulangi problem rendahnya sumber daya, minimnya kesempatan dan menghilangkan masyarakat dari penyakit sosial. 
Program-progam pengembangan masyarakat didesain agar masyarakat marjinal mampu dalam merumuskan terpenuhinya sumber energi, peningkatan ketrampilan serta terciptanya kesempatan untuk hidup yang lebih baikuntuk menggapai hal tersebut para penggerak sosial menggunakan outreach methods ( aktivitas keorganisasian yang karakternya terlibat langsung tidak hanya memberikan pelayanan tetapi juga pendampingan pada anggota masyarakat). Metode ini dicoba untuk membuat kesertaan masyarakat meningkat dalam bermacam aktivitas warga yang mengarah untuk menggapai keadaan kehidupan yang lebih baik dan berdaya.

tujuan dari pengembangan masyarakat diantaranya adalah tumbuhnya partisipasi demokratis dalam struktur masyarakat sehingga diperlukan terciptanya sebuah proses yang memungkinkan masyarakat untuk mengexplore sumber daya dan meningkatkan sumber daya sosial dan keseimbangan dalam struktur kekuasaan.

Secara substansial proses dari Pemberdayaan adalah menghilangkam ketergantungan hubungan antara subyek dengan obyek.

Pemberdayaan adalah sebuah proses menuju berdaya dan kemandirian untuk memutuskan nasibnya sendiri kearah yang lebuh baik. Sistem ini mengandalkan keahlian dari subyek dalam menggali dan mengembangkan kemampuan atau energi( power) yang ada pada diri obyek. Secara garis besar, cara ini menekankan pada pentingnya proses transformasi sebuah daya dari subyek ke obyek. Sehinga output dari proses pemberdayaan ini adalah munculnya subjek baru dari yang semula berperan sebagai obyek. alhasil hubungan sosial yang terdapat bisa digambarkan sebagai hubungan antar sesama subyek. Samuel Paul, misalnya, melaporkan bahwa pemberdayaan berarti pembagian kewenangan yang seimbang sehingga tingkatkan kesadaran politis serta kewenangan kelompok yang lemah serta memperbesar dampak mereka kepada cara serta hasil pembangunan. Pemberdayaan pada intinya yaitu pemanusiaan. Pemberdayaan, bagi Indrasari Tjandraningsih (1996), mengutama- kan upaya sendiri dari orang yang diberdayakan buat mencapai keberdayaannya. Oleh sebab itu, 
pemberdayaan sangat jauh dari konotasi ketergantungan(Bagong Suyanto,2001).

Rancangan pemberdayaan pada intinya tidak dipandang hanya sebatas terpenuhinya kebutuhan yang paling dasar (basic needs) tetapi lebih dari itu. ataupun menciptakan metode buat mengurangi kemiskinan (safety net), ide ini akhir-akhir ini banyak berkembang untuk menganti konsep yang lama. Konsep ini bertumbuh dari usaha banyak ahli seperti apa yang dukembangkan oleh John Freidmann dengan ide alternative development, yang mengharpkan terwujudnya sebuah demokrasi yang terbuka, peningkatan ekonomi, persamaan gender and interge- nerational equity (Bagong Suyanto,2001).

Esensi pemberdayaan merupakan memampukan serta memandirikan masyarakat. Pemberdayaan bukan cuma mencakup penguatan individu anggota masyarakat, namun pula pranata pranatanya. Menanamkan nilai- nilai budaya modern semacam kerja keras, berhemat, transparansi,dan kebertanggung jawaban disebut- sebut sebagai bagian dari upaya pemberdayaan itu sendiri.

Dengan pemberdayaan adalah sebuah upaya terencana, terstruktur dan ada tujuan yang akan dicapai yaitu adanya perubahanan dari objek ke subjek pembangunan, adanya ekskalasi yang terukur dan terencana baik secara kualitas maupun kuantitas, secara kualitas objek perberdayaan secara sumber daya manusia mengalami peningkatan sedangkan secara kuantitas objek pemberdayaan mengalami peningkatan kesejahteraan secara lahiriyah, ekonomi, sosial dan kesehatan.

4. Bank Wakaf Mikro

Pada Oktober 2017, pemerintah bekerja sama dengan OJK dan beberapa pesantren di Jawa Timur mendirikan lembaga pemberi pinjaman bernama Bank Wakaf Mikro (BWM) yang bertujuan untuk mendukung pengusaha mikro di sekitar pondok pesantren. Di balik pembentukan BWM adalah komitmen pemerintah Indonesia untuk mendukung permodalan usaha mikro dan kekhawatiran tentang perusahaan mikro yang kesulitan mengakses permodalan bank karena kurangnya agunan.Risiko tinggi dan biaya suku bunga tinggi. Itu harus ditanggung oleh peminjam. Selain itu, karena banyaknya pesantren di Jawa Timur, maka pemerintah tertarik untuk 
menjadikan Pesantren sebagai lembaga pengelola dana wakaf tunai yang nantinya akan disalurkan ke usaha mikro (Faiq Ramadhan, Raditya Sukmana, 2020:2172-272).

Mekanisme penyaluran dana yang ada tidak didasarkan pada Undang-Undang Nomor 41 Tahun 2004 tentang wakaf khusus yang terkait dengan wakaf tunai. Hal ini karena UU Wakaf mengatur bahwa penyaluran wakaf tunai harus melalui LKS-PWU yang resmi ditunjuk oleh Kementerian Agama. Namun, istilah "Wakaf" Bank Wakaf Mikro sebagai nama lembaganya mudah diterima oleh lingkungan Petani. Mengingat potensi pemberdayaan pesantren yang sangat besar, menurut data Kemenag, tujuan BWM adalah untuk memberdayakan masyarakat berbasis pesantren. Ada 28.194 pondok pesantren di seluruh Indonesia, dengan jumlah terbesar di Jawa Barat. Oleh karena itu, diharapkan jumlah ini akan membuka potensi besar untuk memberdayakan masyarakat, mengurangi ketimpangan ekonomi dan berperan dalam pengentasan kemiskinan, khususnya masyarakat sekitar Pesantren.

Peran lembaga keuangan mikro saat ini masih menjadi hal yang tidak bisa dipisahkan dari perekonomian Indonesia, melihat masih tingginya perhatian pada pengembangan di wilayah mikro dan kecil. Melalui beroperasinya 7 Bank Wakaf Mikro, tentunya kemudahan masyarakat dalam mengakses keuangan dalam skup mikro jangkaunya dapat diperluas. Sehingga para penggiat UMKM dapat ditopang diwilayah permodalan (Faujiah, 2018:375). Fokus dari bank Wakaf Mikro adalah penyaluran akses permodalan dengan sistem mudharabah atau bagi hasil. kepada masyarakat kecil. Dana yang akan dijadikan sebagai pengembangan usaha UMKM berasal dari sumbangan yang sifatnya perorangan, lembaga dan donasi dari dunia usaha yang disalurkan lewat LAZNAS (Lembaga Amil Zakat Nasional). Peran dari Bank Wakaf Mikro lainnya adalah memfasilitasi kebutuhan dana yang bisa diakses bagi para pihak untuk memenuhi kebutuhannya. Salah satu pihak yang biasanya memerlukan dana adalah masyarakat sekitar diwilayah pondok pesantren, dimana fungsi strategis pondok pesantren sebagai bagian dari masyarakat adalah dalam proses 
pemberdayaan dan meningkatkan perekonomian masyarakat. (Faiq Ramadhan, Raditya Sukmana, 2020)

Bank Wakaf Mikro adalah salah satu usaha pemerintah dalam memajukan tingkat perekonomian masyarakat dengan menfasilitasi akses layanan keuangan yang sifatnya formal, sehingga operasional bank mikro/wakaf mekanismenya adalah diarahkan pada pola pemberdayaan ditingkat usaha yang skupnya mikro dan menengah (UMKM). Ini merupakan pengejawantahan dari amanat perpes RI Nomor 82 tentang Strategi Nasional Keuangan Inklusif. Meski bisa dikatakan Bank Wakaf Mikro sebagai lembaga keuangan tetapi tidak sama dengan bank. Dalam posisi ini, perhatian OjK difokuskan pada akses keuangan yang diberikan ke masyarakat luas dan ikut terlibat aktif dalam progam-progam yang didukung oleh pemerintah (Wizna Gania Balqis, Tulus Sartono, 2019: 215231). Izin dari operasi BWM ini dilandaskan pada OjK dan juga diatur dalam UU Pasal 9 Nomor 1 Tahun 2013 tentang Lembaga Keuangan Mikro.

Hal yang diharapkan dari program ini adalah bisa memangkas dan mengurangi tingkat kemiskinan melalui model pengembangan inovatif Lembaga Keuangan Mikro Syariah (LKMS) Pesantren yang perhatianya diarahkan pada komunitas kecil. Akan tetapi hal berbeda diutarakan oleh Azharuddin Lathif M.H., M.Ag. DSN-MUI beliau mengatakan pada Juni 2018 terkait pedoman opersional bahwa DSN-MUI belum pernah mengeluarkan fatwa tentang pedoman pembentukan dan mekanisme operasional Bank Wakaf Mikro (Azharuddin Lathif, 2019). Ide dasar Bank Wakaf Mikro pada dasarnya sama dengan lembaga keuangan mikro berbasis syariah yaitu:

a. Koperasi Layanan Izin Usaha Lembaga Keuangan Mikro Syariah

b. Memberikan pinjaman berdasarkan prinsip Syariah, seperti produk pembiayaan berupa Mudharabah, Murabahah, Cardo

c. Tidak menghimpun dana (tidak menerima setoran)

d. Hasil rendah setara dengan 3\% dalam satu tahun

e. Tidak ada jaminan

f. Memberikan instruksi, pelatihan dan pendampingan 
g. Dibimbing oleh OJK bekerjasama dengan Kementerian Koperasi, pondok pesantren dan masyarakat

Dalam aplikasi tersebut, BWM mempraktikkan akad Mudarabah, dan setelah memberikan pinjaman, BWM mewajibkan peminjam untuk berbagi keuntungan sebesar 3\% dari keuntungan bulanan, tetapi saat ini, BWM dalam akad qardh. Kami juga menawarkan pinjaman atau pinjaman yang baik. Nasabah dapat meminjam tanpa wajib membagi keuntungan yang diperoleh dari BWM, namun harus membayar cicilan BWM yang telah ditentukan sebelumnya sesuai dengan jumlah pinjaman yang dapat dipinjam.

Pada dasarnya Bank Wakaf Mikro memiliki fungsi intermediasi dimana fungsi Intermediasi berperan selaku perantara ataupun badan yg mengaitkan antara masyarakat yang kelebihan dana( surplus) pada masyarakat yang menginginkan dana( deficit) (Faiq Ramadhan, Raditya Sukmana, 2020.

Dalam pelaksanaannya, pendanaan modal dasar Bank Mikro untuk keuangan mikro di komunitas kecil produktif di sekitar lingkungan pondok pesantren akan menjadi donatur yang bisa berasal dari kalangan atau perusahaan manapun, baik dari segi pendanaan. Dana donatur adalah dana yang dihimpun oleh Organisasi Amir Zakat Nasional (Raznas). Selain itu, Laznas mempromosikan dukungan untuk klien Bank Wakaf Mikro, termasuk dukungan bisnis, dukungan manajemen keuangan rumah tangga, dan dukungan keagamaan secara teratur. Bank Wakaf Mikro mendapatkan dana ekuivalen Rp dari para donatur. Dari 300.000 .000 (3 milyar rupiah) menjadi rupiah. 4.000.000.000 (4 miliar rupiah). Namun, tidak semua dana tersebut digunakan untuk menghimpun dana, namun sebagian disimpan dalam deposito di bank umum syariah. Dana tersebut kemudian didistribusikan kepada pelanggan secara tunai (Wizna, Tulus Sartono, 2019: 215-231).

BWM adalah lembaga yang memberikan pinjaman kepada pelaku usaha mikro, membebaskan mereka yang menerima pinjaman dari biaya administrasi dan lainnya. BWM adalah solusi yang melindungi komunitas kecil, memberikan kemudahan akses pembiayaan bagi komunitas kecil, dan 
tidak memiliki pemberi pinjaman. Berfungsi sebagai media bagi peminjam untuk mempersiapkan akses ke lembaga keuangan formal. BWM tidak bekerja sendiri dalam menjalankan misinya. Ada lembaga lain yang membantu BMW menjalankan misinya: Badan Amir Zakat Nasional atau BAZNAS.

5. Peran PT dalam Memberdayakan Masyarakat

Seperti yang telah penulis paparkan di atas, peran Perguruan Tinggi bukan sebatas bagaimana mencerdaskan mahasiswanya, tetapi dituntut bagaimana menjadi problem solver bagi persoalan-persoalan yang timbul di masyarakat, persoalan yang di timbul di sekitar Perguruan Tinggi tersebut, maupun yang terjadi di lingkungan dosen dan mahasiswa berada. Mengacu kepada tugas dan fungsi dosen,yaitu menjalankan pendidikan/pengajaran, penelitian dan pengabdian pada masyarakat.

Program-program berikut dapat dilaksanakan oleh dosen dalm penyuluhan pengabdian masyarakat dan mendukung pemerintah dalam pemberdayaan masyarakat dalam rangka pengentasan kemiskinan (Elsy Rahajeng,2021). :

a. Dosen mengamati potensi daerah tempat penyuluh memberikan pengabdian kepada masyarakat. Apakah daerah tersebut memiliki potensi untuk menghasilkan agribisnis atau produk tertentu, atau apakah daerah tersebut memiliki potensi alam, potensi laut yang tersedia.

b. Dosen mewawancarai komunitas dan bertukar pikiran untuk melihat produk apa yang bisa dibuat komunitas.

c. Inventarisasi potensi keekonomian yang akan dijadikan objek pemberdayaan masyarakat.

d. Mencarikan sumber daya pendukung lainya.

Dengan demikian menjadi tugas dosen yang sedang melakukan pengabdian masyarakat untuk dapat menggali dan dan mengidentifikasi dan mengklasifikasi problem masyarakat dan selanjutnya menggali potensi pengentasan problem masyarakat tersebut. Masalah ekonomi misalnya yang kerab terjadi adalah akses masyarakat untuk dapat memperoleh akses pembiayaan usaha. Para pelaku usaha mikro kecil menengah kesulitan 
mengakses permodalan dari lembaga keuangan. Dengan kehadiran Bank Mikro Wakaf semestinya menjadi solusi yang bisa ditempuh oleh dunia usaha mkiro kecil menengah untuk meningkatkan kapasitas dan kapabalitas usahanya untuk dapat bersaing di dunia usaha.

Peran Perguran Tinggi dengan segala tugas dan fungsinya, sekiranya dapat memanfaatkan program pengabdian masyarakat dosen (tenaga pendidik) untuk menggerakan sektor usaha mikro kecil menengah melalui sistem inklusi keuangan bagi masyarakat melalui pemberian akses jasa keuangan formal. Bank Wakaf Mikro adalah lembaga keuangan formal yang langsung di awai oleh Otoritas Jasa Keuangan (OJK).

Mekanisme pembiyaan yang diberikan Bank Wakaf Mikro tentunya belum secara maksimal diketahui dan kemudian digunakan sebagai inklusi keuangan oleh para pelaku usaha mikro. Di sinilah letak peran strategis Perguruan Tinggi melalui mekanisme pengabdian masyarakat untuk dapat mensosialisasikan keberadaan Bank Wakaf Mikro, sekaligus melakukan pendampingan secara menyeluruh baik mulai dari pengurusan untuk mendapatkan program pembiayaan dari Bank Wakaf Mikro, manajamen baik keuangan maupun manajamen pengelolaan usaha dari aspek produksi, packing dan pasca produksi (marketing).

Hal ini perlu dilakukan bagi Tenaga Pendidik (dosen) karena upaya pemberdayaan adalah upaya yang berkesinambungan yang berjalan secara berkelanjutan untuk mencapai target yang telah ditentukan. Keberhasilan prosen pemberdayaan masyarakat ditentukan seberapa target-target pemberdayaan dapat dicapai, yaitu objek pemberdayaan menjadi berdaya, mandiri dan produktif.

\section{KESIMPULAN}

Perguruan Tinggi sebagai institusi yang strategis untuk dapat berperan aktif dalam rangka pembangunan manusia seutuhnya, malalui mekanisme pengabdian masyarakat Pergurun Tinggi dapat hadir memberikan solusi problematika masyarakat. Keberadaan Bank Wakaf Mikro sebagai lembaga keuangan formal dapar dijadikan atau media (alat) pemberdayaan masyarakat, Bank Wakaf Mikro sebagai inklusi keuangan diharapkan sebagai solusi 
Peran Perguruan Tinggi dalam Pemberdayaan Masyarakat ... Rimanto | 33 DOI: $h$ ttp://dx.doi.org/10.24952/tazkir.v7i1.4111

rendahnya akses permodalan dari lembaga keuangan forman. Di sinilah peran Perguruan Tinggi sebagai mediator dan katalilsator. 


\section{DAFTAR PUSTAKA}

Bagong Suyanto. (2001). "Kemiskinan Dan Pemberdayaan Masyarakat Miskin." "Kemiskinan dan Pemberdayaan Masyarakat Miskin, October 2001. http://journal.unair.ac.id/filerPDF/_3_ Bagong.pdf.

Gania Balqis, Wizna, and Tulus Sartono. (2019). "Bank Wakaf Mikro Sebagai Sarana Pemberdayaan Pada Usaha Mikro, Kecil Dan Menengah." Jurisdictie: Jurnal Hukum Dan Syariah 10, no. 2 (2019): 215-31. https://doi.org/10.18860/j.v10I2.7380.

Mulyawan Rahman. “E Book; Masyarakat, Wilayah Dan Pembangunan,” 2016. http://pustaka.unpad.ac.id/wp-content/uploads/2016/10/04-Buku-OK_opt.pdf.

Faujiah, A, (2018) "Bank Wakaf Mikro dan Pengaruhnya terhadap Inklusi Keuangan Pelaku Usaha Kecil dan Mikro (UKM)," $2^{\text {nd }}$ Proceedings Annual Conference for Muslim Scholars, Tahun 2018

Rahajeng, Elsy, and S Kom. (2021). “Peran Perguruan Tinggi Melalui Pengabdian Kepada Masyarakat Oleh Dosen Dalam Rangka Mendukung Program Pemerintah Dalam Pengentasan Kemiskinan." Accessed May 5, 2021.

Ramadhan, Muhammad Faiq, and Raditya Sukmana. (2020). “Peran Bank Wakaf Mikro Dalam Penguatan Modal Dan Pemberdayaan Usaha Mikro Di Surabaya." Jurnal Ekonomi Syariah Teori Dan Terapan 6, no. 11 (January 21, 2020): 2172. https://doi.org/10.20473/vol6iss201911pp2172-2184.

M. Nazir, “Metode Penelitian” (Jakarta: Ghalia Indonesia)

Muhammad Musa, Metodologi Penelitian,( Jakarta : Fajar Agung, 1988 )

Suryana, Sayan. "Peran Perguruan Tinggi Dalam Pemberdayaan Masyarakat." $\begin{array}{llllll}\text { Pendidikan Rabbani } 2, & \text { no. } & 2 & \text { (2018): } & \text { 368-79. }\end{array}$ https://journal.unsika.ac.id/index.php/rabbani/article/view/1443.

Zubaidi. "Pengembangan Masyarakat; Wacana Dan Praktek." ebook, March 2013. http://repository.iainbengkulu.ac.id/4430/1/Buku Pengembangan Masyarakat \%281\%29.pdf. 